\title{
DEPOSITS OF DEMAND PAPER AS "PURCHASES"
}

\author{
ROSCOE B. TURNER
}

Bank clearings have long been regarded as one of the most valuable indices of the volume of commercial transactions had during a given period. ${ }^{1}$ Implicit in this is recognition of the fact that payments, where more than a few dollars are involved, are today almost universally made by check. It is, of course, recognized, however, that such statistics contain an element of unreliability in that an increase in amount may be accounted for, at least in part, by a greater use of bank deposits, as well as by reason of a greater amount of business done. The movement to popularize the "trade acceptance" ${ }^{2}$ as an instrument to displace the open book account has no doubt contributed to the increase in volume of bank clearings, but without occasioning a corresponding increase in commercial transactions. Possibly it might also be shown that a greater number of time or demand notes have been drawn payable at banks than heretofore, and, like the trade acceptance so payable, have contributed to the aggregate of bank clearings. But whatever their utility to reflect an increase in the volume of business, clearing statistics testify convincingly that bank deposits and the instruments used to avail of deposits are elements of increasing significance in the financial scheme of things. ${ }^{3}$

The development in the use of checks is illustrative. Not so many years ago it was customary for the southern or western merchant, in making payments to his eastern wholesaler, to remit by bank draft, the merchant paying the exchange costs upon purchasing the draft. Checks circulated for the most part only in the immediate vicinity of the depositor. Following the establishment of the national banking system during the Civil War, bringing as it did some measure of stability to banking throughout the country, the widespread use of checks developed. ${ }^{4}$ It is

$\rightarrow$ Edwin Frickey, Bank Clearings Outside New York City, 1875-1914 (1925) 7 Rev. of ECoN. Statistics 252. The data now principally relied upon is the debit to the individual depositor's account as being more accurate in the main than clearing figures. This material since 1918 has been collected by the Federal Reserve Board. For an excellent comparison of the two, see Spahr, The Clearing and Collection of Checks (1st ed. 1926) c. 12 .

2 Westerfield, Banking Principles and Practice (1st ed. 1924) 641.

${ }^{3}$ See SPAHr, op. cit. supra note 1 , at 490 for a table showing the increase in volume of bank debits since 1919.

4 Moulton, Money and Banking (1st ed. 1916) Part II, 37.

[874] 
now customary to use the personal check in making payments anywhere in the country, the costs of collection, if any, normally being borne by the creditor. Indeed the American dollar check has within the last few years been found even in international transactions, where heretofore the foreign currency banker's draft was used almost exclusively.

The issuance of these various instruments constituting drawings upon bank deposits is only one phase of the matter. Of perhaps equal importance is the use to which such paper is put while outstanding. If it is indorsed restrictively and merely handed to an agent for collection, although it would, of course, figure in clearing house statistics, it is of relatively little further service. If indorsed generally and deposited by the holder, the sum being immediately carried to the depositor's account available for drawing, it is evident there are two deposits where only one existed before; the one against which the item was drawn and the one in the holder's favor upon depositing the check. And if the bank on its part uses the item to build up its balances with a correspondent, a further addition to the sum total of deposit currency available in the country at the moment has been made. It is quite possible that before the original item is paid both the original holder and his bank may have drawn against the deposits in their favor, the items in each case serving as the basis for other drawings.

Thus there is built up a credit structure of considerable proportions which, however, is dependant for its fullest development upon the concurrence of a number of factors. Many of these, an elastic currency responsive to fluctuating seasonal demands, the mobilization of bank reserves, an improved collection system, and others contributing to stable banking, have in large measure been supplied by the Federal Reserve system. ${ }^{5}$ It is evident. though, that conflicting and unsatisfactory decisions relating to any of the various steps between issuance and ultimate collection serve to cause trouble. Therefore, it is disquieting that many of the most ordinary legal incidents of deposits of demand or matured paper are still a subject of considerable litigation. It would no doubt be much more disturbing if legal rules pertaining to such deposits had crystalized in the seventeenth century with the inception of banking among the goldsmiths of Lombardy Street. ${ }^{6}$ Possibly something of this very sort has in fact taken place.

The course of judicial legislation as exemplified in some of the leading decisions since the Civil War is enlightening. In the most recent, that of Equitable Trust Company v. Rochling, ${ }^{7}$ the

5 For example see Kniffen, Commercial Banking (1st ed. 1923) c. 6.

6 Moulton, op. cit. supra note 4 , at 10.

748 Sup. Ct. 58 (1927). 
Supreme Court had under consideration several similar deposits ${ }^{8}$ made with the firm of Knauth, Nachod \& Kuhne, private New York bankers, just prior to their failure. It appears that in one of these transactions Gebrueder Rochling, bankers of Frankforton-Main, who maintained an account with Knauth, Nachod \& Kuhne, procured the National Bank of Commerce of New York to deposit $\$ 30,000$ to the credit of this account. The National Bank of Commerce made the deposit by delivering its cashier's check for the amount payable to Knauth, Nachod and Kuhne "for account of Rochling Bank, Gebr. Frankfort-on-Main." Upon receipt of the item Knauth, Nachod \& Kuhne credited Gebrueder Rochling and deposited the item in its own account with another New York bank. The failure occurred before the check had been cleared. Upon this state of facts Gebrueder Rochling claimed to be entitled to reclamation of the proceeds of the check, but the court, by Justice Stone, disallowed the claim.

From the standpoint of abstract legal theory the case was regarded as requiring a decision of whether Knauth, Nachod \& Kuhne should be considered to have received the deposit as "agents" or as "purchasers." The lower court had held, following a supposed analogy to indorsements "for account of," ${ }^{9}$ that a trust or agency relation was created, and so allowed a preferred claim. This position was disposed of with eminent good sense by the court, the words "for account of" being given their ordinary business significance, that is, as being merely an advice as to the account to which credit should be given; written on the face of the instrument for purposes of convenience. ${ }^{10}$ With the

8 The term deposit is used herein in its most general sense and not as a term denoting any particular legal consequences-as, for example, would the term bailment.

๑ In this connection the Supreme Court said: "It may be conceded that such an indorsement indicates that the transaction is not a purchase and sale of the paper, and, at least when not otherwise explained or limited, may fairly be taken to mean that the interest gained by the indorsee is that of an agent for collection." In other words had the National Bank of Commerce made its check payable to self and then indorsed it "for account of Rochling Bank, Gebr. Frankfort-on-Main" the court would probably have sustained the lower court in giving judgment for the plaintiff. It may well be doubted that this would be because a different result was intended by the depositing bank. Although the problem of restrictive indorsements is beyond the scope of this paper, it is believed the court need not have conceded that the "for account of" indorsement negatives any idea of sale, as is the result if the "for collection" indorsement is used. Commercial Bank of Penn. v. Armstrong, 148 U. S. 50, 13 Sup. Ct. 533 (1893). However, under the Negotiable Instruments Law, the "for account of" indorsement has been held restrictive, Gulbranson-Dickinson Co. v. Hopkins, 170 Wis. 326,175 N. W. 93 (1919).

10 The advantage of writing the advice on the instrument is plain in that otherwise a separate writing must be used and for purposes of keeping a 
matter of giving any peculiar significance to these words out of the question, the court had no hesitation in treating the check as equivalent to a cash deposit, as indeed the custom between the banks involved was shown to be; cashier's checks being regarded practically as cash. The result then comes within precedent established long ago that depositors of money are not entitled to preferred treatment over other types of creditors. ${ }^{11}$

In the Latzko case, ${ }^{12}$ decided at the same time as the Rochling case, the check deposited was not a cashier's check, but one drawn on a third bank. This was regarded as a distinction without difference, the controlling feature again being said to be that credit was given on receipt of the item. It also did not appear that the account would bear interest from date of credit, as was the situation in the Rochling case. Although in this case also there was no evidence that the account was subject to immediate drawing, the court stated that this would be assumed. Thus this litigation stresses the matter of giving credit in the drawing account as being the dominant fact going to show "purchase" rather than "agency," at least where the issue is whether or not a preferred claim should be allowed. Of chief interest at the moment, however, is the citation of authority relied upon by the court.

Two prior Supreme Court cases were cited. Of these, that of City of Douglas $v$. Federal Reserve Bank, ${ }^{13}$ in which the opinion was also written by Justice Stone, involved a question as to whether a depositor might recover of a correspondent bank, the Federal Reserve Bank of Dallas, for alleged negligence in sending the deposited item directly to the drawee for payment. The item, a check drawn December 22, 1920, by the County of Cochise, Arizona, in favor of the plaintiff, the City of Douglas, was delivered, indorsed in blank, to the First National Bank of Douglas, Arizona, and credited to the plaintiff's account, the amount also being entered in the passbook. The feature of the case new to the Supreme Court was the passbook provision: "All out-oftown items credited, subject to final payment." In the lower court ${ }^{14}$ it was ruled that an "agency" relation was created, and, following the New York collection rule, it was determined that the depositor had no cause of action against the sub-agent correspondent bank. The case was taken to the Supreme Court on the theory that, granting that an agency relationship was estab-

record of the transaction it is simpler to have the entire story told by the item itself.

11 In the matter of the Franklin Bank, 1 Paige 249 (N. Y. 1828).

12 Latzko v. Equitable Trust Co., 48 Sup. Ct. 60 (1927).

13271 U. S. 489, 46 Sup. Ct. 554 (1926).

14 City of Douglas v. Federal Reserve Bank, 300 Fed. 573, 575 (D. Texas, 1924). See also (1925) 34 Yale LAW Journal 323. 
lished, still the effect of the clause was to adopt the Massachusetts rule so that the Federal Reserve Bank as agent of the depositor could be held directly responsible. The Supreme Court decision for the defendant was given on grounds not discussed by the lower court, Justice Stone saying:

“. . . when paper is indorsed without restriction by a depositor, and is at once passed to his credit by the bank to which he delivers it, he becomes the creditor of the bank; the bank becomes owner of the paper, and in making the collection is not the agent for the depositor."

It is interesting to note that in reaching this result the court cited no case which had had before it the precise question involved in the Douglas case, although several cases were cited which for other purposes had ruled that the bank of deposit should be regarded as a "purchaser." The court apparently rested the case principally on the authority of Burton $v$. United States, ${ }^{15}$ which was cited several times. Here the question before the court was whether an indictment of Senator Burton charging him with having received payment in St. Louis for services rendered before the United States Post Office Department could be sustained upon the evidence. It was admitted that the services had been rendered and that payment had been receivedbut payment was in the form of checks drawn upon the Commonwealth Trust Company of St. Louis, and were deposited by Senator Burton in the Riggs National Bank of Washington, D. C. The Riggs National gave credit for the amount immediately and, as testified by the cashier, this gave the depositor the privilege of drawing at once for the full amount. In this setting the court ruled that the check when deposited belonged to the Riggs Bank, so that payment was made to it and not to Senator Burton in St. Louis. The evidence was therefore held not to support the indictment. The Riggs bank was a "purchaser," not an "agent."

The court in the Burton case did not appear to have made any extensive investigation of the various incidents of such a deposit, but relied almost exclusively on the language of prior cases in which the transaction was described as a "purchase," although in none was the purpose at issue in any way comparable to that involved in the Burton case. The three leading cases cited deserve special notice. The most recent was that of Taft $v$. Quinsigamond National Bank, ${ }^{17}$ decided six years before in Massachusetts. The controversy there was between the deposi-

15196 U. S. 283, 25 Sup. Ct. 243 (1905).

${ }_{16} \mathrm{It}$ is amazing the influence the Burton case has had on subsequent litigation involving purely banking questions. The real issue in the Burton case was primarily one as to how strictly the penal statute in the case should be enforced.

17172 Mass. 363, 52 N. E. 387 (1899). 
tor and the bank of deposit, the Quinsigamond National Bank of Worcester, Massachusetts. The deposit was of a check drawn on a bank located in Edgemont, South Dakota, and payable to the plaintiff. The latter's account was credited on August 2, 1897, when the item was deposited. It appears that the item was promptly sent forward for collection, but the defendant's correspondent sent the item directly to the drawee in Edgemont. No word of its fate was received by the defendant until September 8, 1897. Then, after some endeavor to effect collection, the defendant on November 19, 1897 charged the amount back to the plaintiff when writing up his passbook. Upon these facts the court held that "when, without more, a bank receives upon deposit a check indorsed without restriction, and gives credit for it to the depositor as cash in a drawing account, the form of the transaction is consistent with and indicates a sale, in which, as with money so deposited, the check becomes the absolute property of the banker." The court mentioned, as being consistent with this view but not necessitating the result, that the depositor had been allowed to draw against the credit. Thus the court reached the conclusion that the defendant having purchased the item did not have the power to reverse the transaction. The court cited no authority at all in point for this proposition. ${ }^{18}$

The next earlier case relied upon by the court in the Burton case was that of Metropolitan National Bank $v$. Loyd. ${ }^{19}$ This also involved a deposit of a demand item, but again the question before the court was entirely different from that in any of the preceding cases. On October 29, 1878, Murray deposited with the Merchants \& Mechanics Bank of Troy, N. Y. a check for $\$ 305$ drawn to his order by the defendant. The check, which had been properly indorsed, was credited to Murray's account in his passbook and was then mailed on the same day to the plaintiff, duly indorsed, by the Merchants \& Mechanics Bank, for credit to its account, which was at the time overdrawn.

18 In Heinrich v. First National Bank, 219 N. Y. 1, 113 N. E. 531 (1916), a similar case, the deposited check having remained unpresented for some ten months while reposing behind a radiator in a Philadelphia Post Office, the bank was also refused the privilege of charging the amount of the credit back to its customer.

In the words of Judge Cardozo, "The defendant has suffered loss because checks which it was collecting in its own behalf, as owner and not as agent, miscarried in the mails, and because after notice of the mishap, it slept upon its rights." Accord, although here too the bank showed a practice of giving immediate credit to the depositor in his checking account under circumstances allowing of charge back in case of dishonor. Aebi v. Bank of Evansville, 124 Wis. 73, 102 N. W. 329 (1905). As to the charge back custom the court said: "Such being the transaction, the right of the defendant to charge back the amount of this check or to collect from the plaintiff is only that resulting from the relation of indorsee and indorser."

1990 N. Y. 530 (1882). 
Murray appears to have learned of the failure of the Merchants \& Mechanics Bank before the item was presented for payment and to have had payment stopped. It was argued that the credit given to the defendant was only provisional and that the Merchants \& Mechanics Bank was merely an agent with no authority to sell the item to the plaintiff. The court ruled, however, that when the bank gave Murray credit for the deposit,

"the property in the check passed from Murray and rested in the bank. He was entitled to draw the money so credited to him, for as to it the relation of debtor and creditor was formed, and the right of Murray to command payment at once was of the very essence and nature of the transaction."

No evidence appears to have been introduced to show that drawing would actually have been allowed as stated by the court.

The Metropolitan Bank case was like each of the foregoing in citing no authority squarely in point, ${ }^{20}$ but equally happy in having urged upon it prior cases where for other purposes the banker was deemed an owner of his customer's deposits. Among these, the case of Marine Bank v. Fulton Bank, ${ }^{21}$ relied upon in the Burton case, should be considered. The Fulton Bank of New York in 1861 sent a collection to the Marine Bank of Chicago and, owing to the disturbed state of the currency at the time, authorized receipt of payment in Illinois bills, the same to be retained by the Marine Bank as a deposit. This was done. Illinois currency depreciated and the Fulton Bank, upon drawing against the deposit some months later, was offered payment in Illinois bills. It was held, however, to be entitled to payment in legal tender in an amount equal to the dollar value of the deposit on the day the account was credited. The court stated that upon crediting the Fulton Bank under the circumstances the relationship of debtor and creditor arose and, further, that although the Illinois currency had depreciated it was money belonging to the Marine Bank and in which the Fulton Bank was in no way interested.

The Marine Bank case ${ }^{22}$ serves to point a transition from the

${ }^{20}$ Principal reliance was put on earlier insurance and brokerage cases. In Scott v. Ocean Bank, 23 N. Y. 289 (1861), an insurance company occupied the position of bank of deposit and as it did not appear to have given the depositor credit for the item it was held the transferee was not entitled to retain the proceeds. A prior case, Clark v. Merchants Bank, 2 N. Y. 380 (1849), involved a deposit with brokers who in turn delivered the item to the defendant which collected it and applied the proceeds to a pre-existing debt of the brokers after their insolvency. Here apparently the customer had received credit with authority to draw and judgment was for the defendant.

212 Wall. 252 (U. S. 1864).

22 In Thompson v. Riggs, 5 Wall. 663 (U. S. 1867), also cited in the Burton case, the converse situation was considered. The court decided that 
many cases, of which Foley $v$. Hill ${ }^{23}$ is perhaps best known, where for one purpose or another the relation of depositor and bank has been described as that of debtor and creditor; a generality as to which there appears to be no dissent. From this to holding that the bank of deposit should suffer any depreciation in the particular moneys received, as in the Marine Bank case, was but a step, or perhaps logically only a necessary implication of that holding. The next step, that of saying that the debtorcreditor notion should apply to deposits of demand paper-that the bank was a "purchaser"-was a step of greater length. The Metropolitan Bank case has been criticized as using the purchase idea as a mere device to avoid the rule obtaining in New York at the time that a pre-existing debt would not constitute value. ${ }^{24}$ While superficially this is plausible, still it would seem unlikely that the foregoing series of cases would be based on anything so tenuous. It is clear, though, that the court in the Metropolitan Bank case did not have in support of its position any prior banking authority which had gone so far.

Granting for the moment that the Metropolitan Bank case may have taken new ground, still, whatever one's emotional reaction to the law may be, the foregoing series of cases must seem to the layman like a strange assortment to be regarded almost as conclusive authority for each other. Suppose the court in 1904 did refuse to sustain the indictment of Senator Burton, saying that the Riggs National had "purchased" the check he deposited with it. Is that to be almost controlling authority for the holding in the Douglas case that the City of Douglas should have no cause of action as depositor against a correspondent collecting agent, or that Rochling should or should not be allowed a preferred claim upon the insolvency of Knauth, Nachod \& Kuhne? And is it to be taken more or less for granted that the banking practice prevailing in Douglas, Arizona, in 1920 was the same as the practice of the Merchants and Mechanics Bank of Troy, New York, in 1878, or of the Quinsigamond National Bank in Worcester, Massachusetts, in 1897? Perhaps-but it is doubtful that either consideration is given much weight. On the other hand, while this use of authority may well be subject to criticism, still the actual decisions in each case may be satisfactory. To ascertain this would require a detailed examination into all phases of the subject from the practical viewpoint. An inquiry

deposits of coin made with the Riggs bank in 1861 were likewise not repayable in kind, but, as the relation was merely a general debtor-creditor one, the bank could pay in green backs, legal tender.

$232 \mathrm{H}$. L. Cas. $28(1848)$. Here it was announced that the relation between bank and depositor is that of debtor and creditor, the issue before the court though was merely whether a depositor would be entitled to an accounting in equity.

24 Scott, Cases on Trusts (1st ed. 1919) 67. 
into some of the cases wherein special facts have been urged upon the courts as varying the situation, or in which different issues have been raised, should assist, however, in a determination.

The issue may be presented graphically by visualizing a daily window deposit. Money and bills are, of course, entered in the passbook as cash, but, without any inquiry whatever as to the financial standing of the parties, checks also are credited to the account. According to the legal view of the transaction above set forth, the bank is regarded as having become a purchaser at this point. On the same day, however, should the customer wish to sell to the bank his notes or trade acceptances evidencing business receivables, it would usually be necessary to confer with one of the superior officers of the bank, and much information as to the customer's financial standing, the transactions out of which the items grew and the worth of the other parties to the instruments offered would no doubt be required. And even then credit would not ordinarily be given for the face value, but for face less discount. While, of course, this procedure applies particularly to unmatured time items, demand drafts on out-of-town points, which may be compared with checks drawn on the same points, may be discounted in the same way. In fact, in many cases such items would only be taken as collateral, the customer being required to sign a note for the principal sum, usually less than the value of the collateral. Of course, in either case the proceeds would be carried to the drawing account. But why make the sharp difference in practice if in legal effect the ordinary deposit results in a "purchase"?

Apparently, substantially the foregoing argument was made to the court in the Metropolitan Bank case, ${ }^{25}$ but the court brushed it aside by merely asserting that in fact what the parties had done, as clearly as if it were the result of a formal application for discount, was to "transfer the title" to the check and the bank "charged itself with a debt absolutely due" the depositor. On what were very similar facts, in so far as they were reported in the two cases, a Kentucky court, in Falls City Woolen Mills v. Louisville National Banking Co. ${ }^{26}$ had this to say:

"There was nothing in the transaction to indicate a purchase by the bank of the check. No inquiry was made as to the solvency of the drawer, or of the bank on which the check was drawn. . . . The receiving teller was without authority to buy paper. This power was conferred only on other officers of the bank.

${ }^{25}$ Supra note 19.

26145 Ky. 64, 140 S. W. 66 (1911). See also Strong v. King, 35 Ill. 9 (1864), saying that agency is presumed as to paper taken by a teller. 
This argument is plausible-but it would apply equally to deposits of money or to checks "cashed" rather than received on deposit by the teller. In such cases it is well established that the bank is to be regarded as owner.

The setting of the case before the Kentucky court was quite different from that in the Metropolitan Bank case, which may perhaps explain the difference in viewpoint. In the Kentucky case the plaintiff had deposited with the defendant a check drawn on an out-of-town bank and received immediate credit with the privilege of drawing if desired. There was evidence of a custom on the part of the bank to charge back uncollected items. Here, however, the check was duly paid, loss occurring through failure of a correspondent to remit the proceeds. The plaintiff contended, as was held in the Taft case, ${ }^{27}$ that the bank was a "purchaser" and must bear the loss. Obviously, the item having been paid, the bank had no recourse against its depositor upon his indorsement. But without considering the extent of legal sanction to be given to the charge-back custom, the court decided that the bank was acting merely as "agent" for transmission rather than as "purchaser," and thus reached the result that it was not responsible. ${ }^{28}$

It is apparent from the foregoing that the "purchase" theory when adopted forecloses all discussion of whether the bank of deposit is to be regarded as a collecting agent responsible for acts of its sub-agents, the New York collection rule, or as being an agent for transmission of the paper to proper correspondents, the so-called Massachusetts rule. ${ }^{29}$ In the Falls City case, the court, after refusing the purchase view, applied the Massachusetts collection rule obtaining in Kentucky to reach its result of non-responsibility on the part of the bank of deposit. In the Kirkham case, ${ }^{30}$ arising in New York, a case very similar upon its facts, it was decided not only that the bank as "purchaser" should be responsible to its depositor but, without much discrimination, also apparently that the result might be justified on the theory that the New York bank of deposit as collecting agent was responsible for the acts of its correspondent.

On these limited facts this precise question arises much less often today because of the widespread use by banks of stipula-

27 Supra note 17.

28 It is interesting to compare this case with the Taft case. Both arose in states following the Massachusetts collection rule, that is, that the bank of deposit is not liable for acts of correspondents. In the Taft case there was evidence of considerable delay, however, on the part of the bank, and the court talked purchase. Here the defendant was not directly at fault in any way.

29 For a brief discussion of the two rules, their origin and relative desirability see Comment (1924) 33 Yale LAW JournaL 753, n. 1.

${ }^{30}$ Kirkham v. Bank of America, 165 N. Y. 132, 58 N. E. 753 (1900). 
tions to avoid responsibility. The most common clause, in use before either the Taft or the Kirkham case was decided, read:

"This bank in receiving checks or drafts on deposit or for collection, acts only as your agent, and, beyond carefulness in selecting agents at other points and in forwarding to them, assumes no responsibility." ${ }^{31}$

It appears to have been designed primarily to circumvent the New York collection rule and did so by stipulating for the Massachusetts rule. It is obvious, however, that if given effect according to its literal wording it would constitute a stipulation against the "purchase" notion as well, the relation being defined as one of "agency" instead. ${ }^{32}$ Indeed, the court in the Taft case, while holding the bank responsible on the purchase theory, thus reaching the same result as though the New York collection rule had been applied, stated that had some such clause as this been used it would have been given effect. ${ }^{33}$ In states having the Massachusetts collection rule it became customary to use only a short provision, as in the Douglas case, reading: "All out-oftown items credited subject to final payment." No doubt seems to have existed in the Douglas case but that this would be effective to allow of charging an item back to the depositor. The item in the Douglas case appears, in fact, to have been charged back to the City of Douglas.

The situation of the City of Douglas after the Supreme Court decision had been rendered throws some light on the desirability of the result reached in the Douglas case. The court held that no recovery could be had against the collecting bank for its neg-

31 The court in the case of In re Assignment of State Bank, 56 Minn. 119,57 N. W. $336(1894)$, held that this clause brought about an agency situation and that the depositor might reclaim the deposited items from the receiver of the bank of deposit. It was said the credit under the circumstances was "merely provisional, and the privilege of drawing against it merely gratuitous."

32 Stipulations of this sort however have uniformly been held effective to accomplish their main purpose, that is, to relieve the bank of responsibility for acts of correspondents. A large number of cases might be cited. In Capital Grain \& Feed Co. v. Federal Reserve Bank of Atlanta, 3 F. (2d) 614 (N. D. Ga. 1925), the New York bank of deposit used the following clause "This bank acts only as collecting agent and assumes no liability on account of delay or loss in transit or until it receives final actual peyment from its correspondents." This was said by the court to negative both the purchase and the New York collection agency rule so that suit could be brought directly against the collecting bank alleged to have acted negligently.

33 "So a bank by general notices printed in its passbooks or deposit slips, or otherwise brought to the knowledge of its depositor, or by agreement with the particular depositor as to his own deposit or by crediting paper as paper and not as cash . . . may define its position as that of agent or purchaser." Taft v. Quinsigamond Nat. Bk., supra note 17. 
ligence, there being no privity. The "charge back" by the bank of deposit presumably being sanctioned as well, the depositor was left apparently with no recovery against anyone whatever. There have been few cases going so far. In Downey $v$. National Exchange Bank, ${ }^{34}$ squarely in point with the Douglas case and reaching the same result, the item was charged back to the depositor, apparently pursuant to a charge back provision, although the point was not mentioned, and the court said:

"When the check was returned to the bank of Arlington and was by it turned over to appellant (the depositor) and was by him accepted and charged to his account by the bank, this constituted a resale of the check to the appellant."

Notwithstanding this resale, however, the court refused recovery against the correspondent, stating that there was no privity of contract between the depositor and the correspondent.

The point has caused considerable trouble. ${ }^{35}$ In Weed $v$. Boston \& Maine R. R., ${ }^{36}$ the Maine court followed the supposed implications of the word purchase to the logical extreme. The

${ }^{34} 52$ Ind. App. 672, 96 N. E. 403 (1911).

35 There have been a number of cases where the bank has charged the item back against its customer's account causing an apparent overdraft and yet where the courts have considered the bank still to be owner, the item being retained by it. For example in Royal Bank of Scotland v. Tottenham [1894] 2 Q. B. 715, a post-dated check was deposited, credit being given. Upon its dishonor it was charged back creating an over-draft but the bank was held entitled to collect in full as holder for value. The court said the charge back, at least, was not equivalent to payment.

In Standard Trust Co. v. Comm'l National Bank, 240 Fed. 303 (C. C. A. 4th, 1917), the bank of deposit had forwarded the item through correspondents to the defendant for remittance. The defendant delayed two or three days during which time it might have paid. It then returned the item unpaid to the plaintiff, which charged it to the depositors account, the item being retained. The drawer's account was subsequently exhausted when other unpaid items came back. It was held that under the circumstances the plaintiff was still to be regarded as owner and might recover notwithstanding the charge back. Accord, Union Electric Steel Co. v. Imperial Bank, 286 Fed. 857 (C. C. A. 3d, 1923), where the bank of deposit sued on the retained charged back item. But in Tovrea \& Co. v. Degnan, 27 Ariz. 539, 234 Pac. 820 (1925), it was held that, assuming the bank became owner upon the deposit of the draft, still in view of the charge back, creditors of the depositor might attach the relative goods. Apparently here the charged account was sufficient for the purpose although the point was not mentioned.

The possibility of requiring a receiver of an insolvent bank of deposit to charge back an unpaid deposited item was considered in Bryant v. Williams, 16 F. (2d) 159 (E. D. N. C. 1926). It was held the bank was a purchaser and under no obligation to charge back at the depositor's request. In the case of In re Bank of Minnesota, 75 Minn. 186, $77 \mathrm{~N}$. W. 796 (1899), the failed bank had used the "as your agent" clause and the court required the charge back.

${ }^{36} 124$ Me. 336, 128 Atl. 696 (1925). 
deposit was of a draft with an attached bill of lading for a car of potatoes. While the bank was holding the draft the car was broken into and some of the potatoes stolen. Upon the buyer's refusal to take up the draft the item was charged back to the shipper. Near the end of the statutory period, apparently having no other recourse, the depositor commenced action in his own name against the carrier for alleged conversion. The court cited the Burton case for the proposition that the bank had become a "purchaser" when the item was deposited, and from this it moved to the position that the conversion must, therefore, have been of the bank's potatoes. ${ }^{37}$ The case is of particular interest as the court recognized that the charge back operated as an "assignment" of the bank's rights against the carrier. Nevertheless, it was held that the assignor could only sue in the name of the bank.

Even if a theory of assignment is to be worked out in these cases so as to allow of suit by the depositor against correspondent banks, it has been slow developing and in the meantime many depositors have been deprived of all recovery. ${ }^{38}$ Presumably in any case, the depositor's rights as assignee would be subject to any set-off or defense good against the bank of deposit. Under pressure of this unsatisfactory situation it might be expected that courts would begin to find an "agency" where for other purposes the facts would perhaps still be described as showing a "purchase." In the most recent case possibly explainable in this way, that of Dudley $v$. Phenix-Girard Bank, ${ }^{39}$ the depositor received credit as in the Douglas case, "subject to final payment." With no discussion whatever of the "purchase" idea applied in the Douglas case, the court elected to follow the Massachusetts collection rule rather than the New York rule, thus absolving the bank of deposit from the alleged negligence of its correspondent the Federal Reserve Bank of Atlanta. The court relied chiefly on a late Texas case ${ }^{40}$ where also the bank of deposit was exonerated under the Massachusetts collection rule,

37 Whatever view is taken concerning the bank's interest in the draft, whether as agent, pledgee or purchaser, the documents accompanying the draft, and of course the property covered by the documents, would seem best regarded as collateral for its payment. For example in Wilson Grain Co. v. Central National Bank, 139 S. W. 996 (Tex. Civ. App. 1911), the court said: "It could hold and control the oats until the draft was paid, and if it was not paid could dispose of the oats if necessary to repay itself the money advanced or paid by it for the draft; but it did not in fact buy the oats, and its ownership was limited to the extent above indicated." The situation is ably discussed in Comment (1926) 26 CoL. L. REv. 63.

38 Gulf States Lumber Co. v. Citizens First Nat. Bank, 30 Ga. App. 709, 119 S. E. 426 (1923). This court defeated the depositor because he did not have a formal assignment from the bank.

so 114 So. 188! (Ala. 1927).

40 Tillman Co. Bank v. Behringer, 113 Tex. 415, 257 S. W. 206 (1923). 
while if the Massachusetts "purchase" rule had been applied, as in the Taft case, the bank of deposit would have been held responsible. All of the essential facts relied upon to show a "purchase" appeared in each case. In several other states the same result has been reached, the Massachusetts collection rule being applied. ${ }^{41}$ But in Brown v. Peoples Bank, ${ }^{42}$ the Florida court held the bank of deposit responsible to its depositor where the proceeds of the deposited item had not been received by it due to the failure of the collecting bank. These cases, if we except the Florida decision, indicate that the purchase idea is not looked upon with entire favor in the exact situation presented, that is, where the depositor sues his own bank. It would seem, also, that if the action were against the correspondent the courts deciding these cases would be fairly committed to allowing a recovery, contrary to the results of the Douglas case.

The Brown v. Peoples Bank decision was followed by legislation in Florida providing that the bank of deposit in these circumstances would "only be liable after actual payment received by it." The Supreme Court in the Malloy case, ${ }^{43}$ a decision handed down only a year or so before the decision in the Douglas case, had occasion to construe this statute in a typical purchase situation. The court, however, interpreted the statute as equivalent to the adoption of the Massachusetts collection rule and thus allowed suit to be brought against the correspondent collecting bank, the Federal Reserve Bank of Richmond, for negligence in handling the item. Had the "purchase" notion been given consideration, it would seem that the court logically could no more have applied the Massachusetts collection rule than did the Massachusetts court in the Taft case. True, this would have deprived the depositor of all action, ${ }^{44}$ except again as he might be said to have

${ }^{41}$ Fausett v. State Bank, 21 S. D. 248, 123 N. W. 686 (1909); Wilson v. Carlinsville Bank, 187 Ill. 222, 58 N. E. 250 (1900); Hazlett v. Commercial Bank, 132 Pa. 118, 19 Atl. 55 (1890). It is doubtful though that these courts would regard the bank as in any sense a "purchaser" of the paper and in such case their position on this point is at least consistent. The Pennsylvania court said: "The mere fact that the collecting bank credited him with the check as cash did not alter that relation (agency). This is done daily. Indeed it is the almost universal usage to credit such collections as cash, unless the customer making such deposit is in weak credit. If the check is unpaid, it is charged on again, and the unpaid check returned to the depositor."

4259 Fla. 163, 52 So. 719 (1910).

43 Federal Reserve Bank v. Malloy, 264 U. S. 160, 44 Sup. Ct. 296 (1924).

44 It is intimated in Capital Grain \& Feed Co. v. Federal Reserve Bank, supra note 32 , that this consideration may well have operated to bring the court to its conclusion that suit might be brought against a remote subagent. The decision is remarkable in that there was good authority to the effect that, if the first bank stipulated for the Massachusetts collection rule (and the statute outside of Florida would seem to be of no greater signi- 
taken by assignment a cause of action accrued to his bank, but it would be a situation no worse than that in which the court appears to have left the City of Douglas.

But it is doubtful that the statute ${ }^{45}$ was designed to adopt a "collection" rule to the exclusion of the "purchase" rule. It would seem to have been expressly drawn to relieve the depositor's bank of responsibility for acts of its correspondents. Is such a provision fatal to the purchase notion? May not a bank be a "purchaser" and yet at the same time be held not to bear the risks incident to collection? This was exactly what was stipulated for in the Douglas case by the provision: "all out-of-town items credited subject to final payment." Of course the statute may have gone one step further; it definitely covered the contingency that even though the item should be paid, in the sense that secondary parties would be discharged, still the bank would not be responsible until the proceeds were received by it. But exactly this interpretation has been placed upon the Douglas case stipulation, that is, final payment is said to mean final payment actually made to the bank of deposit. ${ }^{46}$ It may be inferred

ficance) the stipulation would serve oniy to exonerate it, and the next bank in the chain not using such a waiver would be deemed to have assumed the responsibility of an original collecting bank under the New York rule and it alone could be sued for defaults of subsequent banks. McBride v. Illinois National Bank, 163 App. Div. 417, 148 N. Y. Supp. 654 (1st Dept. 1914). The Florida statute was thus not only construed to abolish the purchase rule, but in this situation at least, the New York collection rule.

For a criticism of the holding in the Malloy case on the point that it was negligence on the part of the collecting bank to accept payment by bank draft in the customary way, see Comment (1924) 33 Yale LAw JournaL 752. In the case of Transcontinental Oil Co. v. Federal Reserve Bank, 214 N. W. 918 (Minn. 1927), the Minnesota court in a carefully reasoned opinion refused to subscribe to the views of the Supreme Court on this point.

45 The statute read: "That when a check, draft, note or other negotiable instrument is deposited in a bank for credit or for collection, it shall be considered due diligence on the part of the bank in the collection of any check, draft, note or other negotiable instrument so deposited, to forward and route the same without delay in the usual commercial way in use according to the regular course of business of banks, and that the maker, indorser, guarantor or surety of any check, draft, note or other negotiable instrument, so deposited, shall be liable to the bank until actual final payment is received, and that when a bank receives for collection any check, draft, note or other negotiable instrument and forwards the same for collection as herein provided, it shall only be liable after actual final payment is received by it, except in case of want of due diligence on its part as aforesaid." Fla. Rev. Gen. Stat. (1920) § 4748.

It would seem almost impossible to interpret this as excluding the "purchase" notion although it very carefully provides that the risks incident to collection shall be borne by the depositor.

46 "The words on the deposit slip, 'all items credited subject to final payment' mean that the credit is given subject to the final payment to the bank, and that the credit may be withdrawn if the item is not paid to the 
that the court in the Douglas case did not understand the provision to go so far, and possibly this may be said to be the distinction between the cases, but it is fair to say that there is no intimation in either opinion that this should be the dividing line. Whatever the accepted interpretation of "subject to final payment" may turn out to be, many banks, in the absence of legislation similar to the Florida statute, make it perfectly clear that all risks of collection up to the time when they are in receipt of payment in cash or solvent credits are to be borne by the depositor. ${ }^{47}$

Banking practice has gone a long way to reach this point. It appears that formerly it was not customary for banks to charge back unpaid items to their customer's account. The practice seems to have been to notify the depositor that his item had been dishonored and to request him to make it good. Often this was done by the depositor giving the bank his check drawn upon the account. Possibly this was too slow. At any rate the practice grew up of charging the customer's account, merely notifying him thereafter of the fact. This, by stipulation or by statute, is now sanctioned even where the item has in fact been paid, the loss occurring through the default or failure of collecting banks' remitting the proceeds. There is one limitation, and that is where the bank of deposit has itself been negligent. ${ }^{48}$ Of course, here

bank." Falls City Woolen Mills v. Louisville Nat. Banking Co., supra note 26.

${ }^{47}$ For example in Security Savings \& Trust Co. v. King, 69 Or. 228, 138 Pac. 465 (1914), the clause read: "In receiving checks, drafts or other paper on deposit payable elsewhere than in Portland this bank assumes no liability for the failure of any of its direct or indirect collecting agents whether the collecting agent be the person or concern on which the check for collection is drawn or not, and shall only be held liable when proceeds in actual funds or solvent credits shall have come into its possession. Under these provisions items previously credited may be charged back to the depositor's account. . . ." The court held this effective to allow of recovery by the bank against the depositor for an alleged over-draft when payment had been actually made by the drawee to the collecting bank, but returned because of mistake. It was not yet in receipt of "solvent credits" presumably.

48 In Harter v. Bank of Brunson, 92 S. C. 440,75 S. E. 696 (1912), the clause read: "For value received, we the undersigned hereby agree in depositing the items listed below for collection or credit... that we will not hold the bank liable to us for said items until the cash for each has been paid to the Bank. . . ." It appeared that the bank of deposit after forwarding the item had done nothing about it for several months. It was refused the privilege of charging the items back, the New York collection rule being held to apply. Compare Martin v. Home Bank, 30 App. Div. 498, 52 N. Y. Supp. 464 (1st Dept. 1898), where the court said that inasmuch as the bank of deposit had delayed presentment it could be held responsible whether "agent" or "purchaser." 
too, the result will vary depending on whether the "purchase" or the New York or Massachusetts "collection" rule obtains. ${ }^{49}$

To many courts the very idea of charging back a credit given upon a deposited item is wholly repugnant to the conception of purchase which they entertain. ${ }^{50}$ It is at the same time generally recognized that the secondary responsibility of the depositor to his bank upon the item either in his capacity as drawer or as indorser cannot well be said to conflict. And many courts have sought to reconcile the charge back practice with the idea of purchase by saying that the legal basis for reversing a credit entry of this character is simply that it is merely another means of enforcing the depositor's obligation as a secondary party. ${ }^{51}$ But it is obvious that if this is so it is a somewhat extra-legal method. Indorsees generally proceed in quite a different manner to recover of their indorsers. Furthermore, it is quite apparent that the various clauses such as "credited subject to final payment" were designed for the very purpose of allowing a charge back, say in the situation before the court in the Taft case, where, through delay on the part of the correspondent, the depositor

49 If the bank is to be regarded as in any sense an "agent" rather than a "purchaser" it will probably not be held responsible for the face amount of the item in cases where it can show the depositor was not actually damaged in that amount. The latest holding in New York on the point is Joseph Mogul, Inc. v. C. Lewis Levine, Inc., 247 N. Y. 20, 159 N. E. 708 (1928). The converse would appear to be true in the purchase case. See Kirkham v. Bank of America, supra note 30.

50 The situation presented when a bank reverses a credit given for a raised item or one bearing a prior forged indorsement is of course quite different from the charge back here discussed. See Closter National Bank v. Federal Reserve Bank, 285 Fed. 138 (C. C. A. 2d, 1922), which sanctioned a charge back pursuant to a stipulation that raised items could be charged back at any time. The fact that as to deposits of such kind this may be done would seem to have no bearing on the general problem of whether an "agency" or a "purchase" exists in the usual case. But see an interesting comment, Bank Stipulations to Avoid a Presumption of Purchase in Collection Cases (1927) 27 CoL. L. REv. 73.

51 The court in the case of Noble v. Doughten, 72 Kan. 336, 83 Pac. 1048 (1905), cited with approval by the court in the Burton case, had this to say: "Whether this right may be said to rest merely on custom of banks, or whether the custom has been crystallized into a rule and the right may now be said to be an implied condition attaching to the transfer of the paper makes no difference. It is nevertheless, in strictness, the right of an indorsee against an indorser, and hence is not in any sense inconsistent with ownership."

Although this has become the orthodox statement of the case there would really appear, today, in view of long dealing between the parties, a broader basis for the practice even in the absence of stipulations. It may well be said to have become woven into the bank-depositor relationship. For example the privilege does not appear ever to have been questioned for the reason that the item was not negotiable. And these very courts grant that the custom may well operate as a waiver of strict proceedings upon dishonor. 
would no doubt have been discharged on the item. Of course, the present stipulations definitely providing for charge back even though the item has in fact been paid go much beyond this limit.

It is indeed interesting to observe the attitude of the courts with respect to this changing practice. In the Metropolitan Bank case the court labeled the transaction "purchase," but gave the matter of charge back no consideration whatever. In the Douglas case, and, in this respect it is typical of those courts adhering to the "purchase" rule, the court said:

"While there is not entire uniformity of opinion, the weight of authority supports the view that upon the deposit of paper unrestrictedly indorsed, and credit of the amount to the depositor's account, the bank becomes the owner of the paper, notwithstanding a custom or agreement to charge the paper back to the depositor in the event of dishonor."

It cited as authority prior cases involving different issues, not one of which had had before it a stipulation similar to that in the Douglas case.

By way of further illustration, the problem may be examined from still a different angle, one involving other issues. It is customary in some lines for the seller to deposit his draft on the buyer in a bank with shipping documents attached, receiving immediate credit in his checking account. Well departmentalized banks regard this as a discount transaction as distinguished from a deposit. ${ }^{52}$ In the case of time items, particularly, it is customary to give credit only for the face amount less discount. Demand items payable out of town are often handled in the same way, the discount being calculated on the estimated time the item will require for collection, with an understanding that a further adjustment either way may be made if necessary; or possibly the face amount will be credited and a single interest charge will be made when the item's fate is determined. ${ }^{53}$ As stated earlier, however, in point of legal theory there would seem to be no distinction, for, if ordinary deposits of demand items are regarded as "purchases," all the more clearly the discount of such items, whichever method is employed, would fall in that category. And it does not appear that any court in this

52 WESTERFIELD, op. cit. supra note 2, at 540.

${ }^{53}$ In Vickers v. Machinery Warehouse \& Sales Co., 111 Wash. 576, 191 Pac. 869 (1920) (involving a demand draft) and Walker \& Brock v. Ranlett Co., 89 Vt. 71, 93 Atl. 1054 (1914) (deposit of "on arrival" draft) the depositor was credited with face under such an interest arrangement. In the Weed case, supra note 36 , the credit was apparently of face less discount. In the Ranlett case, supra, the court said, "The arrangement for interest may well have been in lieu of discount; at least, it was entirely consistent with an intention that title to the draft should pass to the claimant." 
country in recent years has taken any distinction in this regard between time and demand items. ${ }^{54}$

Here again the "purchase" theory receives a severe test. Altogether too often the buyer, after taking up the draft and documents, asserts a claim against the seller, usually for alleged breach of warranty, and brings suit by attaching the proceeds in the hands of the local collecting bank. The case is tried at the buyer's point. There is usually some evidence that the buyer may in fact have a bona fide claim. The intervention of the bank from a distant point claiming to be the owner of the draft may readily be made to appear before a jury as but an attempt to save the seller. ${ }^{55}$ And, as might be expected in the circumstances, many courts are far from holding, upon being shown the essential "purchase" facts, that a verdict should be directed for the intervening bank. ${ }^{56}$ Quite the contrary! The case is often submitted to the jury with results adverse to the bank. In Texas a directed verdict for the intervening bank was held error, inasmuch as the court felt that the circumstance that interest was to be charged while the item was outstanding tended to show "agency." 57 And as a matter of procedure, when the case is submitted to a jury, many courts require the bank, as intervenor, to bear the burden of the issue..$^{58}$

54 The case of In re Assignment of State Bank, supra note 31, cited with approval the leading English authority on time paper, Giles v. Perkins, 9 East 12 (1807), although the decision turned largely on the "as agent" stipulation.

55 Townsend Wholesale Grocery Co. v. Chamberlaine Canning Co., 277 S. W. 958 (Mo. App. 1926). The case involved shipment of a car of tomatoes. It is very evident from the report that the jury was enormously influenced by the argument that to defeat the attachment would in effect be allowing the bank to shield its customer, the seller.

56 For example the court in Kaplan v. Ferson Hay \& Grain Co., 140 S. E. 617 (N. C. 1927), approved the action of the lower court in refusing to charge that if the jury believed the evidence it should find for the bank. The North Carolina court, however, is unable to reconcile any possibility of charge back with purchase. In strictness it should have directed a verdict for the buyer, but the result is ordinarily the same if the case is left to the jury.

57 Mayfield Co. v. First Nat. Bank, 287 S. W. 510 (Tex. Civ. App. 1926). The case involved a shipment of beans from California to Texas. It is almost inconceivable that evidence of an arrangement to charge interest would have any value to show "agency"-just the contrary.

58 Townsend Wholesale Grocery Co. v. Chamberlaine Canning Co., supra note 55; Kaplan v. Ferson Hay \& Grain Co., supra note 56; but in Provident National Bank v. Cairo Flour Co., 226 S. W. 499 (Tex. Civ. App. 1921), a case involving a shipment of hay from Idaho to Texas, the jury was instructed that the burden of the issue was upon the buyer. The jury found that he had sustained the burden but the upper court reversed the judgment. The evidence indicated not only that the item had been taken as a purchase, but that drawings had been allowed against it. In Dubuque Fruit Co. v. Emerson \& Co., 201 Iowa 129, 206 N. W. 672 (1926), the court 
In these cases, also, the point most damaging to the bank's position has been the charge back practice. ${ }^{59}$ Most courts, however, here also regard charge back, at least where it appears to be about the same as enforcing the depositor's responsibility as endorser, to be quite consistent with the purchase doctrine. ${ }^{60}$ There is, though, a further consideration appearing in many of these cases, and that is as to the significance which should be attached to actual drawing on the part of the depositor against the credit in his favor. In the orthodox purchase cases the power to draw has been considered to follow necessarily from immediate credit. ${ }^{61}$ In the early Metropolitan Bank case as well as in the late Rochling case, power to draw at once was assumed. ${ }^{62}$ But in the "agency" view drawing has been regarded purely as a concession which the banks might extend or not in its discretion. There is no way in the ordinary case of objectively determining in which way drawings may have been made. ${ }^{63}$ Some

approved a judgment for the intervening bank, the lower court having refused to submit evidence that the bank while holding the item had allowed a reduction in the draft at the shipper's request. This seems quite proper and in accord with the weight of authority. See also National Bk. of Webb City v. Everett \& Son, 136 Ga. 372, 71 S. E. 660 (1911) (judgment on verdict for buyer set aside).

59 The North Carolina statement of the matter is to the point. "The rule prevails with us, and it is supported by the weight of authority elsewhere (?), that if a bank discounts a paper and places the amount, less the discount, to the credit of the indorser, with the right to check on it, and reserves the right to charge back the amount if the paper is not paid, by express agreement or one implied from the course of dealing, and not by reason of liability on the indorsement, the bank is an agent for collection and not a purchaser." Worth v. Feed Co., 172 N. C. $335,342,90$ S. E. 295, 298 (1916).

The rule, announced in a garnishment case, is applied without distinction in other situations. For example in First National Bank v. Rochamora, 193 N. C. 1,136 S. E. 259 (1927), the bank of deposit was not permitted to recover upon a trade acceptance as holder in due course inasmuch as it was regarded as an agent and not a purchaser.

${ }^{60}$ Many cases following the purchase view might be cited but the following are all clean cut decisions on the point: Acme Hay \& Mill Feed Company v. Metropolitan Nat. Bk., 198 Iowa 1337, 201 N. W. 129 (1924); Vickers v. Machinery Warehouse \& Sales Co., supra note 53 ; Walker \& Brock v. Ranlett Co., supra note 53.

In the case last cited the court said: "It (charge back) was, or may well have been, simply a method adopted by the bank to collect from the drawer in case the draft was dishonored."

${ }^{61}$ If a bank fails to honor checks in such situation it may be held responsible for slander of credit. Dirnfield v. Fourteenth Street Sav. Bank, 37 App. D. C. 11 (1911).

${ }^{62}$ Supra notes 19 and 7.

${ }^{63}$ It should be clear also that the matter of following the intention of the parties, stated by some courts as the test, is equally useless. And it is believed the matter of who has the title, with distinctions as to absolute and conditional title, is worse than useless as an aid to deciding these cases. 
courts, nominally inclined to the "agency" view, have, however, looked to evidence of drawing as persuasive of purchase. ${ }^{64}$ The more logical view was taken by the Tennessee court in Barton Seed, Feed \& Implement Co. v. Mercantile National Bank, ${ }^{65}$ in which it said :

"In brief, the bank holds the paper substantially in pledge for credit extended, and it must show the extent of its interest when a creditor of the pledgor seeks to subject it as the property of the latter." ${ }_{66}$

This view would seem, at first glance at least, to hold the balance fairly even between all parties. It is surely immaterial for the particular case if in fact the proceeds are exempted from garnishment, whether the bank is said to be a "purchaser" or a "pledgee." But the possibility of a bank establishing itself as a lien holder, especially where the depositor maintains an active account and in fact has sufficient funds to meet the claim on

You can not determine title, intention, or for that matter whether drawing is allowed merely as a concession, until you have assessed the objective facts involved. Of course having done that there may be some value in translating the determination arrived at into such terms.

${ }^{64}$ Scott v. W. H. McIntyre Co., 93 Kan. 508, 144 Pac. 1002 (1914). Here although (1) interest was being charged until the proceeds were received (2) the item had been numbered as a collection as distinguished from a cash item and (3) privilege of charge back had been reserved, the court regarded the circumstance that the depositor had drawn against the deposit as controlling. It intimated further that this would be true even if the item had been restrictively indorsed, a doubtful point. To the same effect is First Nat. Bank v. McMillan, 15 Ga. App. 319, 83 S. E. 149 (1914) wherein the court said that where drawings have been allowed "the bank acquires title to the goods represented by the bill of lading, and its title can be asserted against the lien of a subsequent attachment creditor of the assignor."

${ }^{65} 128$ Tenn. 320, 160 S. W. 848 (1913). Accord, Sabel v. Planters National Bank, 110 Ky. 299, 61 S. W. 367 (1901), and see Vickers v. Machinery Warehouse \& Sales Co., supra note 53, where the Washington court recognized the lien possibility assuming an agency situation existed. In Groveland Banking Co. v. City National Bank, 144 Tenn. 520, 234 S. W. 643 (1921), the court described the case as one of purchase, there having been drawings and no "agency" or "charge back" clause having been used.

The Tennessee court in the Implement Company case stated its position on the charge back practice as follows: "We are of the opinion that the agreement to charge back in case the paper should be returned is a controlling consideration. It is irreconcilable with absolute ownership on the part of the bank."

${ }_{66}$ The North Carolina court, while still subscribing to the agency view in the ordinary case, has protected the bank against attaching creditors of the depositor, even though the item had been charged back to its customer, it being shown that, both at the time of the deposit and subsequently at the time of the charge back the account was overdrawn almost to the extent of the item. Latham v, Spragins, 162 N. C. 404, 78 S. E. 282 (1913). 
deposit when the attachment is filed, is remote compared with the similar possibility on the purchase theory. ${ }^{67}$ Perhaps some rule based upon the idea that first drawings are made against first credits might be developed to show that the bank's lien interest had accrued even though the account continued in funds, but it is unlikely. ${ }^{68}$ Of course on the purchase view it is immaterial what the state of the account between bank and depositor may be at the time of the attachment. ${ }^{69}$ Certainly if, as has been held, ${ }^{70}$ the attaching creditor prevails providing only it is shown that at the time of the attachment the bank could have hurried to cover by charging its depositor's account, the security afforded by this paper would be wholly illusory. It is believed that the benefits to accrue to all parties from protecting items of this character from attachment far outweigh the procedural gain to an occasional buyer found in allowing the process. ${ }^{71}$

67 It is more than probable that the intervening bank would have the burden of establishing its lien position also while, of course, if it had been viewed as a holder of the draft rather than as an agent it would be prima facie a holder for value, the instrument being negotiable. Tolerton \& Stetson Co. v. Bank, 112 Iowa 706, 84 N. W. 930 (1901).

Those courts nominally following the purchase view which put the burden on the intervening bank to justify its claim to the proceeds present a strange state of affairs. While the draft is held by the discounting bank or its collecting agent it would be a presumed holder of the draft for value with the documents as collateral, but upon payment the position is exactly reversed in these courts.

${ }^{68}$ It is interesting to compare National Bank of Commerce v. Morgan, 207 Ala. 65, 92 So. 10 (1921), an attachment case in which it was shown that at all times the depositor's account exceeded the amount of the item the proceeds of which were being garnished, although drawings to a greater amount had been allowed in the interim. The court assumed, for purposes of the case, that the purchase idea should govern and then proceeded to hold that the bank was not a holder in due course because it had given no value and from this it reached the conclusion that the attaching creditor should prevail. The court took a minority view on what constitutes value refusing to follow Merchants Nat. Bank v. Santa Maria Sugar Co., 162 App. Div. 248, 147 N. Y. Supp. 498 (1st Dept. 1914), and wholly misconceived the problem before it in insisting that the bank should be a holder in due course.

${ }^{69}$ First Nat. Bank v. Milling Co., 103 Iowa 518, 72 N. W. 689 (1897). Here the attachment was served before any drawings were had. See also National Bank v. Bradley, 264 Fed. 700 (W. D. N. Y. 1920).

${ }^{70}$ Wilson Grain Co. v. Central Nat. Bank, 139 S. W. 996 (Tex. Civ. App. 1911). Contra: Sabel v. Planters Nat. Bank, supra note 65. This would appear to be the better position but it would seem probable from the case of National Bank of Commerce v. Morgan, supra note 68, that the Alabama court would follow the Texas case.

71 The language of the dissent in Mayfield Co. v. First Nat. Bank, supra note 57, is pertinent: "If the law should ever be declared to the effect that banks are not entitled to protect themselves in the manner shown here for advancements made to facilitate the handling of grain, cotton and other products in large quantities, such holding would certainly greatly hamper the marketing of such products." 
Strangely enough, few of the cases appear to have discussed the conflict of laws question involved. For example, in the Ferson case $^{72}$ the shipment was of hay from Kansas to North Carolina. The North Carolina court had no hesitation in taking the "agency" view, yet in Kansas, where the bank acquired the paper, the Kansas court in the case of Mercantile Co. v. Bank,,$^{z 3}$ followed the "purchase" theory to defeat attachment, the case involving a shipment of two cars of potatoes from Oklahoma. But to carry the matter no further, it would appear from First National Bank $v$. Munding, ${ }^{74}$ a case concerning a shipment of grain from Arkansas to Oklahoma, that the "agency" view is followed in Oklahoma to allow of attachment. It would seem that the interest of the bank of deposit should be ascertained by the law of the place of deposit. In the principal case considering the question, that of Fourth National Bank v. Bragg, ${ }^{75}$ the Virginia court fortified its decision denying the attachment on the "purchase" theory, by citation of Alabama authority to the same effect, the shipment having originated in Alabama. No doubt if this were followed the "purchase" view would be regarded more favorably in the interest of protecting local shippers. But if the attitude of the courts in the bank collection cases ${ }^{76}$ is to serve as a guide, each court will continue to reach its own conclusion as to whether the ordinary deposit facts constitute a "purchase" or not.

Enough has been said to indicate, without in any sense purporting to exhaust the subject, that there are many considerations to be taken into account. Especially so if only one word as "purchase" or "agency" is to be used to cover satisfactorily all

It would in this view perhaps be desirable to exempt such items from attachment altogether as, even on the purchase view the possibility that the bank will have to go to a distant state to establish its position is enough to make it less ready to take any paper subject to such a contingency. The real protection to the buyer should be in careful inspection before taking up the goods. Certainly the Mississippi view that the collecting bank must retain collected proceeds for a period of ninety six hours, during which apparently the buyer may decide whether or not to attach, does not tend to facilitate commerce. See Alexander County Nat. Bank v. Conner, 110 Miss. 653, 70 So. 827 (1916), a case where the collecting bank became insolvent while holding the proceeds, in which it was held the owner was not entitled to a preferred claim.

72 Supra note 56.

7383 Kan. 504, 112 Pac. 114 (1910).

7483 Okla. 7, 200 Pac. 158 (1921).

75127 Va. 47,102 S. E. $649(1920)$. But as to the Alabama law on the point compare Alexander v. Birmingham Trust \& Savings Co., infra note 86.

${ }^{76}$ St. Nicholas Bank v. State Nat. Bank, 128 N. Y. 26, 27 N. E. 1079 (1891). The New York court here refused to follow a holding of the Tennessee courts adopting the Massachusetts collection rule notwithstanding the item was left for collection with the defendant bank in Tennessee. 
the differing situations and issues brought up for decision. It is also evident that little if any consideration is being given, at least in the reported decisions, to the part such deposits play in the general financial scheme of things. The chief objective appears to be to write in successive cases, although involving wholly different issues, a self-consistent statement of the law, following the supposed implications of the descriptive terms "agency" or "purchase," depending upon which may have been first used in the state. While consistent statement has its value, it should be subservient to desirability of result. And it is at least fairly clear that the present course of decision is no more likely to result in uniformity of opinion among courts generally than it will in entirely satisfactory results in all of the various situations that come before any one court.

It is necessary in order to appreciate the difficulties of the problem before the courts to consider to some extent certain developments in banking. There have been a great many changes during the last seventy-five years. If one looks to the cases decided before the Civil War there is found almost no discussion of the problem; items were apparently received as collections. ${ }^{77}$ In fact, the practice of giving immediate credit with privilege of drawing did not arise except as banking conditions became fairly well stabilized. ${ }^{78}$ Then under the stress of competition, aided by the fact that in many cases such items when sent to city correspondents could be counted at once as reserves, the practice became general, both between city bank and country bank and between depositors and banks. Of course, as the depositor was given credit at face value, it became important for the bank of deposit to route items so that they could be collected as cheaply as possible, even though in a roundabout way. Thus items were sent to banks with which mutual account arrangements were established, each giving the other immediate credit with privilege of drawing, and handling the collection without charge. ${ }^{79}$ Much of this practice is gone. It is no longer customary for banks to maintain mutual collection accounts to any extent; collection items in the Federal Reserve System may not be

77 Allen v. Merchants' Bank, 22 Wend. 215 (N. Y. 1839) ; East-Haddam Bank v. Scovil, 12 Conn. 303 (1837); Fabens v. Mercantile Bank, 23 Pick. 330 (Mass. 1839). The first of these established the New York collection rule and the next two the Massachusetts rule. In none was there any consideration of the idea of purchase.

${ }^{88}$ It was not until sometime after the inauguration of the National Bank system in 1864 that the practice became at all general. The Metropolitan Bank case, supra note 19, decided in 1882 was one of the first to consider what, if any, difference should follow from the fact that the parties, bank and depositor, were apparently treating deposits of checks, much as they would cash.

79 WeSterfield, op. cit. supra note 2 , at $481,482$. 
counted as reserves until collected $;^{80}$ and, although the practice of giving immediate credit to depositors still obtains, it has been hedged about in many ways.

One of the abuses of the system, "kiting," ${ }^{81}$ no doubt contributed to the present change in practice. By opening a local account and one at a distant point a depositor, who alternately deposited in one bank a check drawn on the other, could always have at his disposal without interest and without having had any actual funds, the amount of his checks. This was obviously unprofitable. But, without kiting, something of the same sort occurs whenever drawing against uncollected items is allowed. And from the bank's standpoint it is recognized that the uses to which the paper can now be put are in many cases no longer adequate compensation. As a consequence, some banks stipulate that drawing in such cases will not be allowed. ${ }^{82}$ Others charge

${ }^{80}$ Credit for purposes of reserves is given on the basis of a time schedule arranged according to the average time necessary to collect items drawn on the particular point. The unusual case, that of dishonored items, is subsequently adjusted by being charged back to the member bank's account with the Federal Reserve bank in question. KNIFFin, op. cit. supra note 5 , at 190 .

81 The practice of "kiting" is described in some detail in People's State Bank v. Miller, 185 Mich. 565, 152 N. W. 257 (1915). Here a firm of brokers, which had been in the practice of maintaining fictitious balances with the plaintiff bank, deposited a check drawn by the defendant and were given immediate credit. The firm failed having less real balance in its favor than the defendant's check amounted to. It was held that the plaintiff could not be a purchaser by reason of the fact that it used the usual form of waiver reading "This bank, in receiving check or draft on deposit or for collection, acts only as your agent, and, beyond carefulness in selecting agents at other points and in forwarding to them, assumes no responsibility." The court said: "Under the contract here entered into between the bank and the brokerage concern, it is clear that the bank became the latter's agent for collection of the checks, and could not, it is needless to suggest, be the owner of the paper at the same time."

To the claim that at least the bank's lien interest should be protected the court said that this was not enforceable as the bank, having had some knowledge of the brokerage firms kiting operations, could not be said to have acted bona fide. In this connection it should also be noted that there has long been authority in the Federal courts to the effect that a bank may not retain collections by virtue of its banker's lien, at least as against the real owner, unless it has given new value. Bank of Metropolis v. New England Bank, 6 How. 212 (U. S. 1848) ; Commercial National Bank v. Stockyards Loan Co., 16 F. (2d) 911 (C. C. A. 8th, 1926).

82 The case of In re Jarmulowsky, 249 Fed. 319 (C. C. A. 2d, 1918), involved a claim for preference, the court granting it on the ground that the clause, "Deposits of currency or coin may be drawn against after deposit. but deposits of checks shall not be drawn against until collected," showed that an agency relation existed. To the same effect is In re Farrow's Bank, Ltd. [1923] 1 Ch. 41, the clause being the same although phrased somewhat more circumspectly, "Customers are respectfully informed that the bank reserves to itself the right, at its discretion, to defer payment of 
interest to the extent that drawings may have been allowed against so-called "float," uncollected items. ${ }^{83}$

This development, taken with the agency collection clauses stipulating for non-responsibility for acts of correspondents, and the latest model charge back provisions, would appear to deprive the immediate credit circumstance of almost all of its substance. Are we then to look forward to the probability that in future litigation the tendency will be more and more to adopt the "agency" statement of the case? As indicated above, many courts now consider the simplest charge back custom inimical to "purchase." ${ }^{84}$ The others when faced with the newer provisions allowing charge back even though the item has been paid can no longer say they are merely enforcing the depositor's liability as indorser - and some will no doubt say "agency." Again, if "right to draw" is of the "essence" of the purchase doctrine, it might be expected, as has been held, that stipulations forbidding drawing against uncollected items bring about an "agency." 85 And many courts have read the clause stipulating for non-responsibility for collecting agents as necessarily bringing about "agency" ${ }^{86}$ and negativing the "purchase" doctrine. It is evident that there is much future litigation in prospect.

To assist in unravelling the tangle, let us hold a short conference between the courts and the parties concerned. In the last analysis the courts are engaged in writing, piecemeal, as cases are presented, what in ultimate effect is very similar to a blanket agreement between the parties, so the conference should be pro-

cheques drawn against uncleared effects which may have been credited to the account." The court said: "If the bank had become holder for value of the cheque they could do no such thing."

83 Standard BANking, American Institute of BANking (1924) 124-126. Whether interest is charged in advance as in the typical discount case or not until after collection would seem to be immaterial. Both would be consistent with the "purchase" view.

84 Supra note 59.

85 Supra note 82.

${ }^{86}$ For example, see National Bank of Commerce v. Bossemeyer, 101 Neb. 96, 162 N. W. 503 (1917), wherein the clause read in part: "This bank in receiving out of town checks and other collections acts only as your agent. . . ." See also In re Assignment of State Bank, supra note 31 .

With more carefully drawn provisions the result should be different. But in Alexander v. Birmingham Trust \& Savings Co., 206 Ala. 50, 89 So. 66 (1921), although the court was influenced largely by the charge back feature, an attachment by a creditor of the depositor was held good, notwithstanding the clause avoided describing the bank of deposit as agent. It read: "In receiving checks or other items on deposit payable elsewhere than in Seattle, this bank assumes no responsibility for the failure of any of its direct or indirect collecting agents and shall only be held liable when proceeds in actual funds or solvent credits shall have come into its possession. . . ." 
fitable. It is believed that the banker and the depositor would be fairly in accord on the proposition that the immediate credit system is, in the great majority of cases, quite satisfactory when it means what is usually understood by "purchase." Credit is given at face, there are no collection charges ${ }^{87}$ and the responsible depositor has the privilege of immediate drawing, a credit matter of great importance to him. The bank, regarded as "purchaser," may rediscount the item, collect it through such channels and in such manner as it sees fit, and in further dealings with the depositor be protected as having already become a holder of an actual security. In the normal case the item is paid and the transaction liquidated-a much simpler procedure than loaning against collateral-but one based on the fact that a very high percentage of such items are duly paid. Objectively, the parties no doubt would also agree that the credit to the depositor's account, made in the books of the bank or in the depositor's passbook, should be given almost conclusive significance. ${ }^{88}$

If the courts proceed from this norm, may they square with it the stipulations used by some banks refusing drawings against uncollected items, or the practice of others in charging interest against such drawings? This, to the banker, raises the loan side of the transaction. As a rule a depositor maintains a real balance-not one made up of uncollected items. If the latter is the case, the bank must either close the account, ${ }^{89}$ shift the loss by increasing interest rates or, more equitably, require the unprofitable customer to pay for the accommodation extended. The interest practice has caused little difficulty, it being readily reconcilable with notions of "purchase." ${ }_{90}$ The clauses forbidding drawing are but another way of accomplishing the same purpose. They are of value to the bank only in the unusual

87 It has been estimated in an investigation for the Massachusetts State Legislature that the cost of collecting checks, exclusive of overhead expenses, is 1.5 cents for each check handled as a deposit and 23.7 cents for items handled as collections. PAToN, Digest (1926) § 1776.

88 The court in the case of In re Farrow's Bank, Ltd., supra note 82, intimated that should the bank have received the item for "collection" it could not on its own motion become a "purchaser" by merely entering it in its customer's account. In the great majority of cases, though, it may be assumed, there being nothing expressly to the contrary, that a deposited item may be so credited. The point is not discussed in the American cases. In event, however, that the entry in the depositor's pass book is of paper as, for example, "Check on First Nat. Bk. $\$ 1000$," it has been held that an "agency" rather than a "purchase" is established. Bailie v. Augusta Savings Bank, 95 Ga. 277, 21 S. E. 717 (1895).

89 See Jaselli v. Riggs National Bank, 36 App. D. C. 159 (1911).

$90 \mathrm{It}$ is interesting to note that the practice of many banks in making a small fixed charge should the depositor fail to maintain an average balance of a specified amount has never been called in question in these cases. The interest charge serves a somewhat similar purpose. 
case, the unprofitable account, for as a matter of practice, in the case of ordinary account banks make no objection whatever to an occasional drawing against uncollected items. Certainly a clause having such limited application need not be construed as coloring all deposits with the "agency" brush. ${ }^{91}$

The issue which would cause the parties most difficulty, as it has the courts, would concern another relatively unusual situation, the case of losses occurring in collection. Essentially, the matter is one for bargaining between the parties and one which the courts can do little about, at least so long as they recognize so-called freedom of contract and enforce the "without responsibility" and "subject to final payment" bank stipulations. As a matter of fact, though, the courts themselves in the absence of either statute or stipulation have been in many cases inclined to relieve the banks of this risk. ${ }^{92}$

It would seem, then, that the principal problem before the courts is merely one of so writing their opinions as to record the result. Obviously, to use the word "purchase," at least as usually understood, to describe the entire situation is inaccurate, for in the usual case so described the buyer would bear all subsequent risks, ${ }^{93}$ and of course might not charge back or reverse the transaction. But to attempt to sum up the contract in the one word "agency" is to be much more inaccurate, and allow an incidental matter, one of importance only in the unusual case, to outweigh all other elements of the transaction. In sales law there has been no insurmountable difficulty in the way of treating a buyer as "owner" and yet allowing a stipulation that the seller should bear the risk of loss in transit. ${ }^{94}$ Of course, the bank's stipulations for the most part are designed for much the same purpose. ${ }^{95}$ There was no other way open to them.

91 The court by Judge Hough, in the case of In re Jarmulowsky, supra note 82 , refused to consider this argument, however. It no doubt would have refused utterly to consider the argument that even in the case of the unprofitable account, where the clause was designed to apply, the stipulation would not be necessarily inconsistent with the "purchase" view, the case being one of purchase on a deferred payment basis.

92 See the cases cited supra notes 39,40 and 41 , in which the courts adopted the Massachusetts collection rule to deprive the depositor of a suit against his bank, which he would otherwise have had on the purchase theory. Of course this contemplated that suit might be brought against the correspondent at fault. And this was so in some cases although the correspondent had failed.

93 Uniform Sales Act, § 22.

94 WillistoN, Sales (2d ed. 1924) § 302. This point is suggested in Comment (1927) 27 CoL. L. REv. 73, 75 n. 13.

95 This is clearly so in the case of the "subject to final payment" clause and in the case of many others which merely stipulate for non-responsibility for losses in transit with privilege of charge back (for example see supra note 47 ) but it must be noted that the "as agent" phrase goes beyond the point. It seems more than probable that this latter terminology, originally 
It would be preferable to disregard the terms "purchase" and "agency" altogether and recognize that a broader formula is needed to serve as a rule of decision. ${ }^{96}$ In such case there should be no difficulty in allowing a depositor to sue sub-agents for their negligence, contrary to the Douglas case, ${ }^{97}$ and yet, for example, in the garnishment cases to refuse to allow attachment by the depositor's creditors. ${ }^{98}$ While this may seem like attempting to blow both hot and cold at the same time, it is only so on the assumption that either "purchase" or "agency" as usually understood must serve as a starting point. To make such an assumption is to allow words to dictate decisions. However, it may be predicted that courts will be slow to abandon the supposition that their decisions must be restricted to a choice between either "agency" or "purchase." 99

used merely to contract out of the New York collection rule as to actual collections, was simply continued as to deposits primarily to avoid collection risks and not in order to negative the "purchase" rule.

${ }_{96}$ The often quoted rule that the relation between bank and depositor is that of debtor and creditor, for example, while useful as a rule of decision in many cases is of course not a complete statement of the case. To illustrate, in Tournier v. National Provincial and Union Bank of England [1924] $1 \mathrm{~K}$. B. 461, the bank though spoken of as a "debtor" was held to be under a duty to treat its depositor's account as confidential. See Comment (1923) 33 Yale Law JournaL 859.

${ }^{97}$ It should be noted in this connection, however, that the terms on which a correspondent bank undertakes to handle the paper should be those it arranges with the depositor's bank, and it has usually been so held. See Transcontinental Oil Co. v. Federal Reserve Bank, 214 N. W. 918 (Minn. 1927). This means that if the correspondent stipulates that it may forward items directly to the drawee or may accept a bank draft in payment, the depositor would have no cause of action on that account.

98 This result was reached in American Trust \& Savings Bank v. Austin, 25 Misc. 454, 55 N. Y. Supp. 561 (1898), aff'd 47 App. Div. 635, 62 N. Y. Supp. 1131 (1900), a garnishment case in which Judge Hiscock said: "If plaintiff discounted and thereby became the absolute owner of a draft for a customer, and the draft for any reason was not paid, it would naturally expect to charge it back to the customer's account or compel him in some way to make it good. In the case of a draft so discounted and payable in a distant city, it would be necessary for the plaintiff to utilize a line of collecting agents, and any one of them through failure or insolvency might defeat the collection of the draft and place plaintiff where it might desire to charge the same back against its customer. And as I look at it this rule (that the bank in receiving checks or drafts on deposit or for collection acted only as agent and beyond carefulness in selecting agents assumed no responsibility) was intended to cover that part of its transactions with its customers, and as to those acts to make the customer responsible and relieve the bank from liability except within the limits named by the rule." Accordingly, the bank was regarded as a purchaser and allowed to defeat the attachment. This was cited with approval in National Bank of Ashtabula v. Bradley, 264 Fed. 700 (W. D. N. Y. 1920).

${ }^{99}$ In a very comprehensive review of the cases in this field in (1912) 11 Mich. L. Rev. 122, under the title Bank Deposits and Collections, the writer Ralph J. Baker, concludes with the observation that the two rela- 
It is not as though the courts adopting the "agency" view are impelled to take that course to protect the depositor, who admittedly is in a weak bargaining position, for it does not appear to work out that way. For example, in the situation presented by the Taft case, the "agency" view relieves the bank, not the depositor, if the Massachusetts collection rule obtains, and if the New York rule, the bank's stipulations accomplish the same end. In the garnishment cases the "agency" rule clearly operates to the disadvantage of both bank and depositor. And today, in the cases typified by the Metropolitan Bank decision, where the bank of deposit becomes insolvent after having forwarded the item to a correspondent to which it was indebted, the correspondent would prevail as holder in due course, regardless of whether the bank of deposit was "agent" or "purchaser." 100

Only in the situations typified by the Douglas and Rochling cases would the agency rule favor the depositor. In the first of these his gain may be largely one of simplified procedure, for at least the depositor, as assignee of the purchasing bank of de-

tions, debtor and creditor or principal and agent, are mutually exclusive and that it has been the failure to observe this which has caused the confusion in the cases.

100 The issue is presented most often in cases where the bank of deposit uses an "agency" clause and then forwards the item to a correspondent which subsequently brings suit on the item, for example against the depositor. Here if the correspondent bank gave immediate credit to the forwarding bank and allowed withdrawals, there has been no difficulty in sustaining the correspondent bank's position as one of purchaser for value. Blacher v. National Bank of Baltimore, $151 \mathrm{Md}$. 514, 135 Atl. 383 (1926); National Bank of Commerce v. Bossemeyer, supra note 86; United States National Bank v. Amalgamated Sugar Company, 179 Fed. 718 (D. Or. 1910).

But where the bank bringing suit on the item had itself used such a stipulation, there has been more difficulty, although, if there had been drawings, recovery is usually allowed on some basis. Bank of California, National Assoc. v. Young, 260 Pac. 227 (Or. 1927). In the closely contested case of Old National Bank of Spokane v. Gibson, 105 Wash. 578, 179 Pac. 117 (1919), the bank of deposit as plaintiff sued the drawer, the check having been deposited by the payee who had been allowed to check out the amount. The drawer relied upon the clause, "Items other than cash are received on deposit with the express understanding that they are taken for collection only" to show "agency" and thus to defeat the bank's cause of action. The majority held that the plaintiff was a holder for value and that in the particular case it was unnecessary to distinguish between lien and purchase. The four dissenting judges took the view that if the bank was to be regarded as having taken the paper as an agent it could not subsequently convert its position into that of a holder for value by allowing "gratuitous" drawings. In Jefferson Bank v. Merchants' Refrigerating Co., 236 Mo. 407, 139 S. W. 545 (1911), the court was faced with the same situation and said: "we are warranted in holding that the indorsement printed on the cover of the deposit book of the Produce Company, to the effect that plaintiff only received out of town checks subject to collection, had been waived by plaintiff bank-a right it unquestionably had." 
posit, has some possibility of recovering against sub-agent correspondent banks for their negligence. In the second, involving the contingency which the parties probably concerned themselves least about, if the bank is regarded as holding the deposited item as "agent" the depositor may be given a preferred claim. ${ }^{101}$ It is believed that this result, however well established, is essentially unfair to the other depositors, the principal creditors of the failed bank, in that it is purely fortuitous. Other depositors may perhaps have deposited an equal amount on the day preceding the failure, but in cash. Both would have received immediate credit with the same privilege of drawing. Of course, if the depositor of the item had indorsed it restrictively with the understanding that it should be handled on a collection basis, no privilege of drawing being extended, much might be said for allowing a preferred claim. ${ }^{102}$ But otherwise the situation would be one peculiarly within the province of the courts to adjust, charged as they are with taking all elements of the problem into account. On such analysis the "purchase" result reached by Justice Stone in the Rochling case is much to be preferred.

The same difference of opinion exists, however, in the insolvency cases as where other issues are presented. The older view, proceeding upon the theory that the term "deposit" signifies a species of bailment, thus allowing of reclamation, has largely disappeared.103 Those courts regarding "charge back" as inconsistent with purchase, however, as might be expected, give preferred claims, although obviously the situation would not have developed to the point where the charge back provision could be called into play. ${ }^{104}$ The same is true of the provision by which the bank reserves the privilege of withholding payment of checks drawn against the deposit until the proceeds have been received. ${ }^{105}$

101 The point is well established. St. Louis \& San Francisco R. R. Co. v. Johnston, 133 U. S. 566, 10 Sup. Ct. 390 (1890). This case appears to be out of harmony with the later supreme court cases in finding an agency under the circumstances before it, but it would be sustained on its further ruling that as the bank was hopelessly insolvent to the knowledge of its officers at the time of the deposit, a preferred claim should be allowed. Craigie v. Hadley, 99 N. Y. 131, 1 N. E. 537 (1885).

102 National Butchers \& Drovers Bank v. Hubbell, 117 N. Y. 384, 22 N. E. 1031 (1889) (preferred claim allowed in case of "For collection" indorsement).

103 Balbach v. Frelinghuysen, 15 Fed. 675 (C. C. N. J. 1883). Cited with approval ScoTT, op. cit. supra note 24 , at 67 . This is representative of a number of early cases allowing preferred claims in circumstances which it is believed the supreme court would today unhesitatingly regard as requiring the opposite result.

104 For example see Armour Packing Co. v. Davis, 118 N. C. 548, 24 S. E. 365 (1896); Miller v. Norton \& Smith, 114 Va. 609, 77 S. E. 452 (1913) ; Alleman v. Sayre, 79 W. Va. 763, 91 S. E. 805 (1917).

105 In re Jarmulowsky, supra note 82. 
And most courts construe the "as agent for collection" clauses as necessarily bringing about the same result. ${ }^{106}$ This seems like undue emphasis of incidental matters to produce an unfortunate result.

While it may perhaps be demonstrated, on paper, that the courts and parties could reconcile their positions, and that to the advantage of all concerned, still very little progress is being made to that end. Some endeavor has been made from the standpoint of the banks to bring about uniform stipulations. ${ }^{107}$ These are designed primarily for bank protection. And, even if widely adopted, it is evident that there is no assurance whatever that the courts will interpret them in any uniform way or with much regard to the larger questions of policy mentioned above in the first few paragraphs.

One alternative would be to wholly abandon the "purchase" idea, and take items exclusively on an "agency" basis, no credit being given to the checking account. If so, the depositor should perhaps be advised, for his better protection, to indorse restrictively - thus avoiding losses, for example, in the situation presented in the Metropolitan case among others. This course would compare, although perhaps remotely, with recommending that depositors withdraw their balances and keep their money privately. Certainly it would permit of only a limited use of what otherwise serves as a valuable security. Drawings would be allowed, if at all, on an overdraft basis, a custom prevailing in foreign banking but not usual here, or the depositor would be required to execute notes as required, possibly pledging his collections as security. This would be a needlessly expen-

106 In re Assignment of State Bank, supra note 31.

${ }_{107}$ In 1925 the General Counsel for the American Bankers Association recommended the following form for adoption by all banks: "In receiving items for deposit or collection, this bank acts only as depositor's collecting agent and assumes no responsibility beyond the exercise of due care. All items are credited subject to final payment in cash or solvent credits. This bank will not be liable for default or negligence of its duly selected correspondents nor for losses in transit, and each correspondent so selected shall not be liable except for its own negligence. This bank or its correspondents may send items directly or indirectly, to any bank including the payor, and accept its draft or credit as conditional payment in lieu of cash; it may charge back any item at any time before final payment, whether returned or not; also any item drawn on this bank not good at close of business on day deposited." Paton, Digest (1926), Opinions 1446, 1446 a.

It is to be noted that most courts would read the words "as depositor's collecting agent" to bring about an agency, a result believed to be unsatisfactory in many ways. This clause is not necessary nor is it believed to be advisable in the many states having the Massachusetts collection rule. Of course, in any case many courts would seize upon the charge back provision as indicative of "agency." For the banks own protection it is thus probably not desirable to use the clause in the case of discounted items whose proceeds may be garnished. 
sive system; not to be compared with the properly safeguarded immediate credit system in flexibility and responsiveness to business requirements.

Possibly a sounder suggestion would be for banks to reverse their traditional practice and hereafter assume all risks of collection-much as the New York collection rule would have it. There would thus be no reversal of the transaction except, of course, in the case of dishonored items which had been properly handled. There has been no possibility of adopting such a course by any bank individually, for the failure of a single correspondent collecting bank might bring about losses sufficient to wreck the forwarding bank. However, it would be possible to insure this risk, the premium being charged to the depositor each month on the basis of the amount of such paper put through during the period. ${ }^{108}$ In view of the present position of depositors this would seem to be quite worth while protection to them. From the standpoint of society, in addition to the gain to result from the elimination of much of the needless litigation on the "purchase"-_agency" controversy, a result which would probably follow from omitting the charge back, and non-responsibility clauses, an economical system of adjusting losses between banks informally could be worked out without requirement of litigation. Actually bank collection losses should be settled between banks, ${ }^{109}$ a result in large part accomplished indirectly in countries having nation-wide branch banking.

This would at once, however, raise many questions fully as unsettled, or if settled as unsatisfactorily settled, as those discussed above-the matter of what constitutes due diligence in handling collections, in what medium collections may be made, and a number of others. The practice of Federal Reserve Banks in forwarding items directly to the drawee or paying bank would need to be sanctioned. The status of items indorsed for "collection and remittance" in event of the insolvency of a collecting bank would have to be determined. ${ }^{110}$ There is no good reason, how-

108 It is not uncommon now for a seller to insure his factory, his stock in trade, certain risks in transit (although the risk is usually upon the buyer), the account receivable and even the paper the buyer's obligation is written on against forgery-only the bank collection losses are uncovered. 109 In the case of carriers, a similar result has been accomplished by the Carmack Amendment to the Interstate Commerce Act, providing that the initial carrier should be responsible to the shipper although the loss occurred on a connecting line. See Basila v. Western Union Tel. Co., 24 F. (2d) 569 (S. D. Fla. 1928), holding, however, that this does not apply to the transmission of money by telegraph.

110 It would seem to be advisable to accord the owner of such paper a preferred claim against the collecting bank holding the proceeds at the time of its solvency. And the more or less artificial rule of the Federal courts as to augmentation of assets could well be abandoned. $\mathrm{S} \rightarrow \mathrm{Com}$ ment (1927) 36 YALE LAW JourNAL 682. It is interesting to note that 
ever, for not actually doing something to agree upon these points. ${ }^{111}$

It may be that the most promising way, whatever decision is to be reached on these points, will be to draft uniform legislation. ${ }^{112}$ In this way there is greater assurance that the interests of all parties, depositors, creditors, buyers as well as banks, will be given due consideration, and, further, that the significance of bank deposits in their relation to the financial system will be taken into account. The legislation respecting negotiable instruments, although far from perfect, has, it is believed, fully justified itself. It surely is of as much importance that the law concerning the deposit and collection of such paper should be satisfactorily stated and made uniform.

North Carolina has recently adopted legislation substantially to this effect. See discussion in (1928) 6 N. C. L. REv. 175.

111 It has for many years been recommended that a uniform bank collection law be adopted. See Paton, op. cit. supra note 107, Opinion 1450, dated 1911.

112 Such legislation as applied to National Banks would present many constitutional law problems. See Davis v. Elmira Savings Bank, 161 U. S. 275, 16 Sup. Ct. 502 (1895), in which a New York statute giving savings banks as depositors in national banks a preferred claim was held invalid. This problem is being raised in the absence of statute. See Central National Bank v. First National Bank, 216 N. W. 302 (Neb. 1927). In many situations, however, there would be no conflict and as to those requiring such action Federal legislation could no doubt be had. 